\title{
Differential Threat Perceptions: How Transnational Groups Influence Bilateral Security Relations ${ }^{1}$
}

\author{
Gary Winslett \\ Boston College
}

\begin{abstract}
This article addresses how transnational groups affect the security relationship between the states they reside in. I argue that this is determined by the differential threat perceptions of the host states. If the host states both consider the group to be a threat, the group is a shared problem and policy toward the group becomes an arena for cooperation for the two states. However, if one state views the group as a threat and the other does not, policy toward the group becomes an arena for conflict between them. I test this hypothesis with a comparative case study analysis of Turkey's relationships with the United States, Syria, and Iran vis-à-vis the Kurds after the United States' invasion of Iraq in 2003.
\end{abstract}

Turkey and the United States have traditionally had quite amicable relations and yet in 2003, they had, according to one of the most venerated historians of Turkish foreign policy, the most serious crisis in their relationship in nearly three decades (Hale 2007:83). ${ }^{2}$ That relationship deteriorated still further over the following years. Almost as quickly, animosity turned into close working relations again in late 2007 and early 2008. The Turkish-Syrian relationship has historically been characterized by hostility, to put it mildly, and yet in October 2007 the Syrian ambassador to the United States told Syrian expatriates that Turkey was Syria's closest ally (Matthews, Walls, Kohen, Peraino, and Hastings 2007). Turkey and Iran have been longtime regional rivals, and yet by August 2007, their security relationship was so tight that when a guerilla organization known as the Party of Free Life of Kurdistan (PJAK) shot down an Iranian helicopter along the IranIraq border, six Turkish army officers were among the casualties (Hawlati 2007). On the surface, these events are baffling, but when we examine the role that transnational groups play in states' threat perceptions and how those threat perceptions drive bilateral security relations, they make quite a bit more sense. Indeed, the seemingly baffling nature of these events demonstrates just how powerful differences or similarities in those states' threat perceptions of a transnational group can be in shaping their respective foreign policies.

Transnational groups are frequently important components of multiple states' security environments. How do these groups affect the relationship between the states they reside in? I argue that this question can best be answered by examining

\footnotetext{
${ }^{1}$ I thank Tim Crawford, Colin Rawls, Alexia Ash, my wife Becky Winslett, and two anonymous reviewers at Foreign Policy Analysis for their very helpful comments and suggestions.

${ }^{2}$ All translations of Turkish language materials are the author's.
} 
the two states' threat perceptions of the transnational group. ${ }^{3}$ If both states perceive the group as a threat, the group creates cooperation between them. If, however, only one of those states perceives the group as a threat, the group creates conflict between them. If a state sees a transnational group as threatening its security, it will seek to suppress that group. If the state does not perceive it as threatening, it will not do so. What is less obvious is that this creates friction between two states sharing a transnational group if they answer that question differently. The difference between State A's threat perception of the group and State B's is what I term the differential threat perception, and it significantly influences the extent of cooperation or conflict between the two states.

If State A perceives Group X to be a threat, then it will attempt to suppress the group and will want State B's cooperation. But if State B does not perceive Group $\mathrm{X}$ to be a threat, then it will not want to crack down on the group out of risk aversion; that is, it does not want to antagonize a group that currently poses no threat. The relationship between the two states becomes more conflict-based as State A asks for State B's help and State B refuses, thereby passively undermining State A's security. This conflict between the two states is more than just policy disagreement. It can spawn a deeper breakdown in relations between the two states in two ways. First, when State B refuses to help State A, State A may retaliate against State B, creating animosity toward State A in State B, which may lead to its own retaliation and a tit-for-tat cycle that drives the relationship into a downward spiral. It also encourages mutual suspicions and hard feelings that only exacerbate tensions. The US-Turkey case examined here suggests how disagreement over transnational groups can sour relations even between longtime allies. For example, after Turkey refused to allow the United States to use its territory as an invasion route into Iraq, the United States rescinded a 15 billion dollar aid package, which in turn precipitated a sharp drop in the Turkish stock market and angered Ankara (Thomas 2003; Weisman 2003). A few months later, after the "Hood Event" (discussed below), Turkey threatened to close its airspace to American planes ("Turkish Fury at Iraq 'Arrests"” 2003). Second, a highly different threat perception opens the possibility for State B to use the group to challenge State A inside its borders. ${ }^{4}$ Because it does not perceive the group as a threat, it need not worry about strengthening the group. Using the group as a pawn is strategic only if the group does not present a threat to both states. It is under these conditions that we most often see policy toward Kurds used as leverage against another state. Hafez al-Assad supported the PKK but felt free to do so only because Kurds presented no domestic challenge to him. Israel supported Kurds under Barzani when they were conducting an insurgent campaign against Baghdad in the 1970s (Gause 2009:35). They were able to do so only because Kurds were a threat to Iraq, but not to Israel. Iran supported the PUK during that period for similar reasons (Gause 2009:37). It is under these conditions that most proxy conflict occurs.

Conversely, if both states view Group X as a threat, their relationship becomes more cooperation-based as they work together to combat the shared problem presented by Group X. The greater the shared problem, the greater the level of cooperation between them will be. If the problem becomes more than just a nuisance-if it becomes a major threat-cooperation between them moves from desirable to imperative. It is at this point, the point at which a nuisance becomes a threat, that concerns over the transnational group become more likely to trump other considerations. When the group is perceived as a nuisance, but not a major threat, other aspects of the relationship will likely dictate policy. In this nuisance

\footnotetext{
${ }^{3}$ By transnational group, I mean a group that is self-conscious and identifiable by its ethnicity, religion, tribe, or language and has sufficient presence in multiple states to be politically salient in them. I borrow and modify this definition from Myron Weiner (1971).

${ }^{4}$ Gregory Gause examines examples of these cross-border challenges (2009).
} 
zone, if other security-pertinent variables such as relative power, alliance structures, or asymmetric leverage dictate cooperation, State B will likely assist State A in repressing the group. If those variables dictate conflict, State B is unlikely to help suppress the group. A good example of the variability in this nuisance zone is the Jordanian-Israeli relationship vis-à-vis Palestinian militants in the 1960s (Shemesh 2002). During this time, Israel conducted multiple raids into the West Bank. The Jordanian government initially tolerated this because both they and the Israeli government felt threatened by Palestinian militants. Once these raids became more public after the Israeli raid at As Samu, antigovernment riots broke out that challenged the Jordanian regime's domestic control even more thoroughly than Palestinian militants had. The Jordanian government soon found itself participating in the 1967 Six-Day War lest it be overthrown as insufficiently anti-Zionist. Faced with a nuisance, the Jordanian government cooperated with Israel when, and only when, it was convenient.

It is important to elucidate what moves the perception of a group from "not a threat" to "nuisance" to "threat." Numerous factors can lead a group to being deemed a nuisance. They can be either material (the group occupies valuable land) or ideational (the group is seen as violating norms cherished by powerful factions in State A). What it is important, however, and what defines nuisance as nuisance is that this perceived problem is not so strong to warrant conflict with the group on its own but encourages that state to side against the group in the event that another state perceives the group as a threat and other aspects of the relationship dictate cooperating. ${ }^{5}$ What moves the perception of a group from nuisance to threat is the group aggressively seeking national independence and/ or terrorism. ${ }^{6}$ Given this definition of threat, a necessary precondition for the transnational group to actually pose a threat to the states in question is that the group must contain a violent armed wing. Without this, the transnational group can only be, at most, a nuisance. That armed wing is the agent that carries out the threat against the state, but because it is nested within the transnational group, it implicates the group as a whole. This is why even though the armed wing is the entity that performs the acts that threaten the state's security, the state's response-and by extension the international dynamics examined in this article-is aimed at the transnational group as a whole. Thus, even though the transnational movement and its armed wing(s) may be fractured across state lines, policymakers are still likely to be concerned with factions other than those that directly threaten them. For example, even though it was primarily the PKK that threatened Turkey and different though allied Kurdish groups that operated in Iraq, the fact that the PKK and the Iraqi groups were perceived to be nested within, and at least to some degree representative of, the larger Kurdish movement meant the actions of the Iraqi Kurdish groups-and of the United States toward them-were highly significant to Turkish leaders. ${ }^{7}$

\footnotetext{
${ }^{5}$ Being deemed a nuisance is especially likely if the group is not helping the state in some other way.

${ }^{6}$ These actions threaten the state's security by challenging both its domestic sovereignty- "the ability of public authorities to exercise effective control within the borders of their own polity" - and its Westphalian sovereignty"the exclusion of external actors....from the territory of the state" (Krasner 1999:3-4).

${ }^{7}$ This does not imply that state leaders will not differentiate between factions of the group. This definition of threat suggests why states sometimes have seemingly inconsistent policies toward different factions in a transnational group. If one faction does not present a terrorism or independence threat, a state may ignore it while simultaneously attempting to suppress another faction that does present those threats. This explains why Turkey in the 1990s supported the KDP in Iraq while fighting the PKK and why Turkey, Iran, and Syria signed an agreement to stem border crossings from Iraq even while they all meddled in Iraqi affairs (Gunter 1998:33-40). What made the Kurdish dynamic in the post-US invasion of Iraq environment much more threatening than the 1990s dynamic was that after the invasion, Iraqi Kurds could potentially get their own state or de facto independence in a highly federalized state, which could in turn inspire independence movements or terrorism in Iraq's neighbors. This also helps explain why Turkey largely supports the KDP-associated KNC in Syria, which pushes for greater economic interdependence and cultural rights, but opposes the Democratic Union Party (PYD) which is much more secessionist and violent (International Crisis Group 2013:ii).
} 
Differential Threat Perceptions

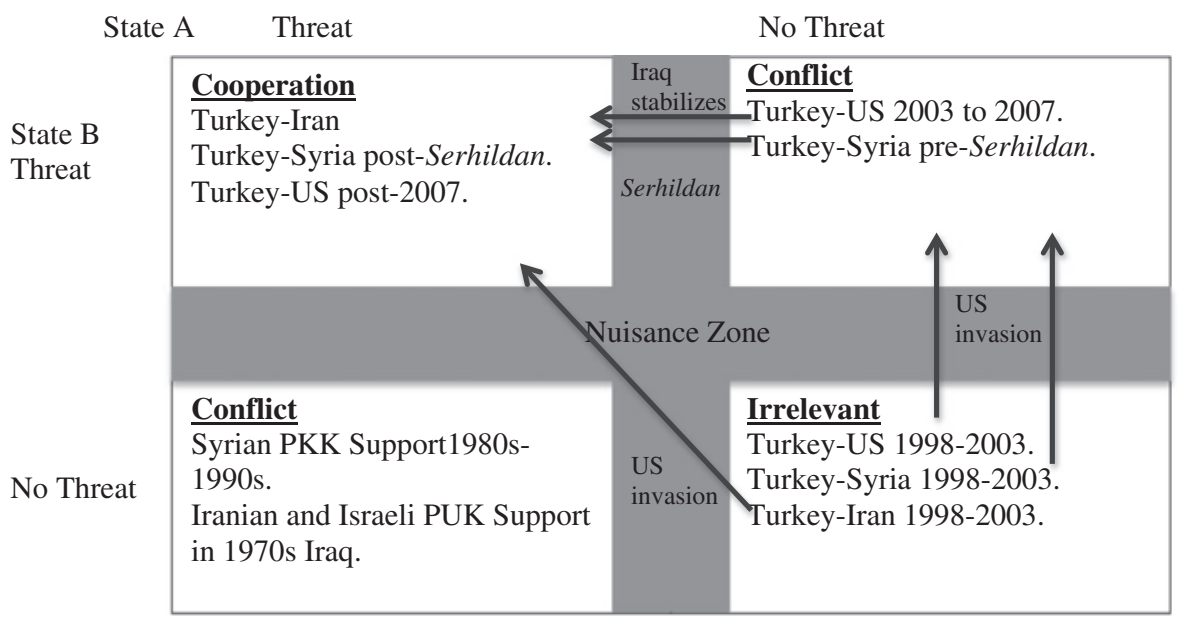

To test this hypothesis, I examine three cases: Turkey's relationship with the United States, Syria, and Iran after the 2003 US invasion of Iraq. There are four advantages in selecting these cases. First, Kurds are a sizeable, politically significant minority in Turkey, Iraq, Iran, and Syria, meaning they constitute an important component in each state's internal security dynamics and thus can influence these states' relationships. Selecting a smaller or less significant group would increase the probability that other factors would overpower considerations concerning the group. Second, these cases hold constant a large number of variables. In all three, the time period, transnational group, and event that created the policy context (the US invasion of Iraq) are the same. One-half of the bilateral relationship (Turkey) is held constant. This combination thus isolates the independent variable (difference in states' threat perception of the transnational group) in explaining the dependent variable (bilateral security relations). Third, given that the Kurds are one of the world's largest stateless ethnic groups, in an examination of transnational groups, there is intrinsic value in studying cases that involve the Kurds. Fourth, using these cases means that while this article does not gain the advantages of using large-N quantitative analysis, it does allow enough space to analyze the cases at many points in time. In this way, each case becomes many data points instead of one. We can be more confident in the hypothesis examined here if it holds in the cases at time $x$ as well as times $x+1, x+2, x+3$, and so forth.

\section{Literature Review}

Mohammed Ayoob (1992:65) argues that developing states face a security predicament that arises from the strain of state-making and states' inability to insulate themselves from international forces. ${ }^{8}$ A dynamic common to many developing states is that they did not draw their own borders; groups that sit astride these boundaries directly impact the security predicaments developing states face. Myron Weiner (1971) has argued that these transnational groups influence international

\footnotetext{
${ }^{8}$ Ayoob assumes state weakness, but my hypothesis does not depend on state weakness. One might respond that weak states are more vulnerable to security threats posed by transnational groups, but all states are vulnerable to some degree and must interact with other states to pursue their security goals. To define a strong state as a state invulnerable is to place the definitional bar impossibly high. Thus, because this article does not depend on state weakness, the literature on state weakness has been left aside.
} 
security relations by fostering what he calls "the Macedonian Syndrome," in which states form particular kinds of alliances in response to irredentism and whether the group is a majority in one state or a minority in both. While his analysis is appropriate if we assume irredentism, I contend that this assumption is usually unwarranted and thus makes his analysis inappropriate in many cases. States' security can be challenged without irredentism. Given this, it is appropriate to ask how transnational groups influence international relationships in which neither state hopes to shift borders. Second, in Weiner's analysis, the group must be a minority in at least one country but may be a minority or majority in the other (1971:668). This article focuses on cases in which the transnational group is a minority in both states. ${ }^{9}$ Another argument concerning states' responses to transnational groups is Stephen Saideman's (2001:12) which argues that "the existence of ethnic ties between decision makers' supporters and the combatants in conflicts in other states will greatly determine the foreign policy of states." I attempt to refute that claim by arguing that a different factor (differential threat perceptions) drives states' foreign policies with regard to transnational groups. It may be the case that a decision maker's supporters sharing ethnicity with a group affects threat perceptions, but still it is the threat perception, not the shared ethnicity, that is the key factor.

Salehyan (2010:vi) conducted a review of transnational rebellions in an attempt "to determine patterns of conflict and cooperation over transnational militant groups." He finds that where conflict emerges over transnational militant groups, it is because one of those states supported the group, and where cooperation occurs, it is because the states view the group as a common problem (Salehyan 2010:8-15). Salehyan's examination is not incorrect, but it is under-theorized. Why exactly do states choose to support these groups and what leads them to view a group as a shared problem? This article builds on his work by answering those questions and explaining the theoretical underpinnings of states' policies toward transnational groups. My analysis also differs from his in two other ways. First, he is focused on the execution of policy rather than the motivations behind policy. Salehyan is interested in determining "best practices" (2010:vi). For example, he argues that states, in response to transnational rebels should delegate greater authority to local security personnel, improve bilateral communication, increase intelligence sharing, and promote diplomacy (2010:ix). This leads him to miss the real drivers of cooperation and conflict. If states have similar threat perceptions of a transnational actor, then cooperation is bound to flourish even if the execution of such cooperation is imperfectly implemented. Conversely, if the group is a threat to State A, but not State B, State B has little incentive to cooperate to begin with. If the threat perceptions of the two states differ, how best to cooperate becomes a moot point. Second, Salehyan (2010:6) attributes conflict to somewhat trivial details. He argues that events such as "hot pursuit raids across the border to chase rebels may lead to clashes with border guards and spark interstate war." Again, this dynamic would be superseded by threat perceptions. These hot pursuit raids and other details of policy execution may be important in the nuisance zone, as they were in the As Samu example, but in cases where there are clearly different or clearly similar threat perceptions, it is the threat perceptions that drive policy execution, not the reverse.

\section{Turkey and the United States in Iraq}

In Turkey, Kurdish nationalism gave birth to the Kurdistan Workers' Party $(\mathrm{PKK}),{ }^{10}$ which launched its first attack in Turkey in 1984; over the next fifteen

\footnotetext{
${ }^{9}$ This focus is what also differentiates this work from Davis and Moore who analyze situations in which the transnational group is the minority in State B but controls State A's government (Davis and Moore 1997).

${ }^{10}$ The PKK has changed its name multiple times. For clarity's sake, I refer to it as the PKK throughout this article.
} 
years, the insurgency cost Turkey $\$ 15$ billion and left dead almost 5,000 Turkish troops and 35,000 people (Mango 2004:217-219). Prior to the US invasion of Iraq, Turkey's Kurdish areas were stable for the first time in nearly two decades. After the US invasion, the Kurdish issue became a point of friction between Turkey and the United States. For Turkey, Kurdish militancy constituted a nearly existential threat. For the United States, Kurds constituted the lone friendly group in a country filled with adversaries. This difference in threat perception meant the United States and Turkey repeatedly clashed over security policy with respect to northern Iraq.

In the lead-up to the war, the United States asked Turkey to allow it to use Turkish territory to open a northern front in its invasion. Turkey's political leaders were reluctant because they feared the invasion could lead to a renewal of Kurdish political problems (Çevikcan 2002). A power vacuum in northern Iraq could revive PKK terrorism. An independent or highly autonomous Kurdish regional government could lead to demands for secession or similar autonomy among Turkey's Kurds. No element of Turkish policymaking was solidly in favor of the war. The CHP, the major opposition party, was resolutely opposed (Asik 2003). The leaders of the AKP government were worried. The Turkish military feared that the United States would give weapons to Kurdish militias (peshmergas). Massoud Barzani, a prominent Iraqi Kurdish political leader, exacerbated these fears by promoting an independent Kurdistan (Dogan 2003). While the Kurdish issue was not the only reason for Turkish reluctance, it was the most prominent fear for Turkish policymakers; prior to the Turkish parliament's vote, Prime Minister Erdoğan intimated that should the war happen, Turkey's primary objective was preventing Kurdish independence in northern Iraq (Filkins 2003). As Hale (2007:13) notes, US officials underestimated the strength of this Kurdish dynamic in Turkish opinion; they were "insufficiently sensitive towards, or simply oblivious to, the roots and depth of Turkish feeling on the Kurdish issue." On March 1, 2003, the Turkish Parliament voted down legislation to allow US troops to launch their second front from Turkey (Radikal 2003:264-269). US officials reacted with stunned disbelief (Fox News, March 28, 2003).

While representing a potentially huge security threat to Ankara, the Kurds were helping the Americans. They were by far the most pro-US group in Iraq (Katzman 2010:2). During the invasion, the Kurdish peshmergas captured Mosul and Kirkuk before handing them over to American forces and entered Baghdad fighting shoulder-to-shoulder with US troops (Tahiri 2007:319; Ziadeh 2009:7). In return, the United States publicly favored the Kurds. General Garner's reference to Kirkuk as a "Kurdish" city, reports by Iraqi Turkmen that the United States was siding with the Kurds, and the election of an interim government predominated by Kurds all combined to convince Ankara that the United States was firmly supporting the Kurds in Iraq (Park 2005:31). Additionally, when reports surfaced that Turkey had sent 1,500 troops into Iraqi territory, the US government informed Turkey that given its parliament's decision, it would not be allowed to have any significant military presence in Iraq (Hale 2007:115-116). Matters got worse in July with the "Hood Event" in which US troops arrested 11 Turkish soldiers in northern Iraq and kept them hooded while they were detained; the incident generated national outrage in Turkey (Milliyet 2003). Then in September, the PKK officially ended its ceasefire with Turkey (Milliyet 2003). The potential security threat was turning into a real one. 5,000 PKK members were in northern Iraq and were now launching attacks into Turkey, but American military commanders remained reluctant to suppress them because they did not want trouble with the one group that they were not already fighting (Hale 2007:131). Turkey was not being allowed to pursue the PKK and so asked for US assistance. The only response Turkey received was a diplomatic version of "that's not our problem" (NTV Turkish Television 2003). Later in September, the US Senate made an $\$ 8.5$ 
billion loan to Turkey conditional on it not entering Iraq without US permission (NTV Turkish Television 2003). Then, when Turkey offered some PKK members an amnesty, the US criticized the amnesty offer as too narrow (Barkey 2005:19). Turks were infuriated by what they perceived to be the double standard of being expected to cooperate with the United States against al-Qaeda while the United States ignored the PKK (Hale 2007:131). As 2003 rolled into 2004, cooperation between Kurdish and American forces increased and along with it animosity between Ankara and Washington.

In addition to the resurgent terrorism threat, the possibility of an independent Kurdish regional government that might provoke unrest among Turkey's Kurds was growing. In March 2004, the US-backed Coalition Provisional Authority passed the Transitional Administration Law (TAL). This law outlined Iraq's governance structure until it enacted a new constitution. The TAL was highly favorable to the Kurds. It recognized the peshmergas as the internal security force in the Kurdish region, while not recognizing similar militias elsewhere in Iraq. The TAL stated that a new Iraqi constitution could be defeated by a two-thirds majority in three or more provinces and thus gave the Kurds, with an overwhelming majority in three provinces, veto-power over any new constitution (Park 2005:29). The TAL refused to comment on the final status of Kirkuk, which given the peshmergas' control over the area, gave the Kurds time to displace Arabs, which is exactly what they did. ${ }^{11}$ Kirkuk is important because it is ethnically contested and controls ten percent of all Iraqi oil reserves (Katzman 2010:7). Ankara wanted to ensure that Iraq's oil revenue remained under central rather than regional control because it did not want the Kurdish Regional Government (KRG) to be able to use that revenue to bolster its autonomy (Milliyet 2003). Hoping to solidify their gains, the Kurds began to engage in state-building, a development welcomed by the United States. While armed Kurds stabilized parts of Iraq, other armed Kurds were destabilizing southeastern Turkey. In summer 2004, PKK attacks in Turkey intensified; there were 109 attacks that killed 35 Turkish personnel and wounded 94 (Park 2005:44). The sum of all Turkish fears was being realized. The Kurds seemed to be building an independent state in northern Iraq while reigniting terrorist attacks in southeastern Turkey and were being de facto protected by a foreign power. The US-Turkey relationship was souring quickly, and behind this souring was the fact that the same group Turkey viewed as a nearly existential threat was the closest local ally of the United States.

In the fall of 2004, as violence in Iraq grew worse, and as the United States became closer with the Kurds, the United States received less and less benefit of the doubt in Turkey. When the United States assaulted the Turkmen-populated town Tel Afir in September, Turkish media reported huge civilian casualties and that the American goal was to give the town to the Kurds (Barkey 2005:9; Hürriyet 2004d). During the US assault on Fallujah in November, chairman of the Turkish Parliament Mehmet Elkatmiss stated that the United States was committing genocide (Hürriyet 2004). In December, American and Kurdish forces were accused of murdering five Turkish security guards near Mosul (Barkey 2005:11). Late 2004 was the point at which the United States and Turkey were the furthest apart in their respective threat perception of the Kurds and consequently was the lowest point in the US-Turkey security relationship.

From this point on, the difference in Turkish and American threat perceptions of the Kurds lessened though did not totally converge. Three developments helped bring this about. First, the Turkish government began instituting reforms to relax domestic tensions with its Kurds. The AKP had lifted the ban on publishing in Kurdish in 2003, but the effects of this started to become apparent in late

\footnotetext{
${ }^{11}$ Nine months after the TAL was passed, one-quarter of the 200,000 Arabs in Kirkuk had been removed and replaced with 100,000 Kurds (Park 2005:32).
} 
2004 (Dilanian 2004). There was also a change in rhetoric on the Kurdish issue from Turkey's political leadership. In August 2005, Prime Minister Erdoğan traveled to Diyarbakir, southeastern Turkey's largest Kurdish city, and delivered a conciliatory speech on Turkish policy toward the Kurds, and repeated the same message in following speeches (Milliyet 2005). These acts impressed Kurdish voters enough that when they next voted in parliamentary elections in 2007, they voted for the AKP at even higher rates than they had in 2002 (Dismorr 2008:127). This détente on the Kurdish issue softened Turkey's threat perception of the Kurds and its fears of spillover effects from Iraq (Hale 2007:146).

Second, Iraqi Kurds started to politically align with Iraqi Shias. Though they are mostly Sunni, Iraq's Kurds have traditionally coexisted better with Arab Shias than Arab Sunnis due to their suffering at the hands of Saddam's Sunni Ba'athist regime. Iraq's ethnic geography also played a part in this; Sunni rather than Shia Arabs populate the mixed neighborhoods on the edges of Kurdish territory (Economist 2009). This results in a greater frequency of conflict between Kurds and Sunni Arabs than between Kurds and Shia Arabs. The Kurds also wanted to consolidate their political gains. As the most stable part of Iraq, the Kurds' negotiating position strengthened as the rest of the country descended into sectarian strife. Iraqi Shias needed the Kurds to achieve the two-thirds of majority needed to pass the new Iraqi Constitution and so entered into a coalition with them, accepting Kurdish demands for considerable autonomy and installing a Kurd, Jalal Talabani, as President (Ahmed 2007:158). As Iraqi Kurds became more involved in national government, the threat of independence and spillover decreased.

Third, one of most prominent Kurdish politicians, Jalal Talabani, began backing away from full Kurdish independence. Regardless of the fact that $98.3 \%$ of Kurds had voted for independence in a symbolic referendum, Talabani understood that creating a new country from territory possessed by four states was simply not feasible (Park 2005:7-8). He believed that the best way to defend Kurdish interests was to engage in national-level politics (Dodge 2005:51). This was why Ankara supported Talabani as President of Iraq; they believed that if Iraqi Kurds felt they had a vested interest in a unified Iraq, they would be less likely to push for independence (Hale 2007:148).

As Ankara's threat perception of the Kurds decreased, the rancor between Turkey and the United States started dissipating. Gone were the accusations of war crimes and disloyal allies. However, there could not be a further reduction in Turkish threat perception until the PKK stopped attacking Turkey. That did not happen. The only other way that Turkish and American perceptions could more fully align would be for the United States to start viewing the Kurds as a threat, but given that Iraq was descending into a sectarian civil war and the Kurds were the only group not attacking US soldiers, that too did not happen. In February 2005, Secretary of State Rice visited Turkey and had a meeting with Prime Minister Erdogan though nothing was agreed to (Milliyet 2005). In June, Prime Minister Erdoğan visited Washington where he asked President Bush for greater effort against the PKK; again, nothing was agreed to (Milliyet 2005). A commission between Turkey, the United States, and Iraq was created, but after achieving nothing, was disbanded (International Crisis Group 2008:6-7). This lack of American assistance against the PKK continued to stymie the US-Turkey security relationship.

On a separate issue, however, Turkey's relationship with Iraq's Kurds were improving. The new Iraqi constitution was passed in October. From Turkey's perspective, the new constitution was a significant step forward. First, it solidified the federal character of the new government and so dampened Kurdish independence desires. Second, it did not legally prescribe Kurdish control of oil resources in its territory (Hale 2007:149). With this new constitution, Ankara's 
worst fear (an independent, oil-rich Kurdistan) was now a much more remote possibility than it had been a year earlier. But just as this worry was becoming more remote, Ankara's other major concern (PKK terrorism) was getting much worse.

The PKK significantly increased the frequency and intensity of its attacks on Turkey in 2006 (Marcus 2007:295). In March, a suicide bombing in Diyarbakir killed two and wounded eighteen (Milliyet 2006). In the following days, the PKK killed a Turkish sergeant at Gabar Mountain, five soldiers in Sirnak province, and bombed AKP offices in Istanbul (Milliyet 2006b; Hürriyet 2006a). In April, Secretary Rice visited Turkey and delivered vague promises about greater efforts to stem PKK-related violence from Iraq; Turkish exasperation with empty promises spanned the entire political spectrum (BBC Monitoring Europe 2006). It did not help that US-made weapons were found in the PKK's possession and that PKK deserters stated that "US trucks delivered weapons to their camps in the Qandil Mountains" (Kaya 2012). An internal Department of Defense investigation revealed that US troops had in fact sold weapons to Kurdish militants (International Crisis Group 2008:6). At the same time, the number of attacks seemed to be ever increasing. During a three day period in July, the PKK killed fifteen Turkish soldiers (Hürriyet 2006b). The number of violent incidents and casualties related to the PKK had fallen to essentially zero by 2002 but then skyrocketed after the US invasion of Iraq, reaching more than 1,000 by 2007 (Unal 2012:63). That simple correlation was highly salient to Turks. Not only did many Turks see the United States as having caused the problem, but every time an American diplomat visited and every time a bomb detonated, Turks were reminded that rhetoric aside, the United States in its War on Terror was doing very little to thwart the terrorists attacking Turkey.

Much as before, the reason the United States did nothing was because even though Kurdish militants terrorized Turkey, they hugely helped the United States in Iraq. Even as the PKK was launching a fresh wave of attacks in the spring of 2007 and Massoud Barzani was telling Iraqi Kurds they could begin attacking Turkish forces, Kurdish peshmergas were assisting the American troop surge in Baghdad (Shaikh 2007; Katzman 2010:4,11). By fall 2007, Turkey had had enough. Faced with the US unwillingness to fight the PKK in Iraq and with terrorist attacks reaching levels unseen in over a decade, the Turkish Parliament voted overwhelmingly to allow the government to make large-scale incursions into Iraq to suppress the PKK (Milliyet 2007).

Meanwhile, something interesting happened, something that was unexpected and that changed US threat perceptions of Iraq's Kurds. Violence in Iraq decreased. In 2006, the average number of people killed was 2,381 per month. ${ }^{12}$ For the first eight months of 2007, the monthly average was 2,574. For September 2007, the total was 1,286. For October, November, December 2007, and January 2008, the totals were 1,226, 1,080, 936, and 763, respectively. The use of the most destructive and terror-inducing method (suicide bombing) also decreased. Over the first eight months of 2007, the average number killed by suicide bombings was 427 per month; the average over the last four months was 112.

A number of factors caused this reduction in violence. First, sectarian violence had unmixed most of the religiously mixed neighborhoods. In majority Sunni areas, Sunni militias had killed or chased away Shias. In majority Shia areas, the reverse had happened. The number of religiously mixed neighborhoods in Baghdad dramatically decreased from April 2006 to November 2007 (DeYoung 2007). With less sectarian contact came less sectarian violence.

\footnotetext{
${ }^{12}$ These figures and the ones that follow are from Iraq Body Count.org.
} 
Second was the al-Sahwa in which Sunni leaders struck security deals with American troops. Al-Sahwa meant Sunnis were now working to hold Iraq together rather than driving the insurgency. With Sunnis no longer attacking Shias, Shias could return the favor. The Mahdi Army (the largest Shia militia) calling a truce also helped. The US troop surge also arguably contributed to reducing violence. Additionally, the United States was beginning to negotiate a new Status of Forces Agreement that would shift much of Iraq's security burden onto Iraqis. Taken together, all of this meant the United States could see the exit. With Iraq becoming safer and with the United States preparing to hand security responsibilities to Iraqis, the Kurds were suddenly no longer indispensable. Furthermore, Washington very much wanted to patch up its relationship with Ankara. That made the policy of continuing to tolerate the PKK to not offend Iraqi Kurds an expendable policy, and expended it was.

Once Washington's threat perception of the Kurds shifted closer to Ankara's, policy toward the Kurds became an arena for cooperation between them. In November, President Bush pronounced the PKK "an enemy of the U.S." and more importantly promised that the United States would begin sharing greater intelligence on the PKK with Turkey (Dombey 2007; Myers 2007). The United States soon began delivering on that promise and Turkey put that intelligence to good use. On December 2, Turkey launched air strikes against PKK positions in Iraq (Milliyet 2007). On December 16, Turkey launched more than fifty sorties in their largest strike yet (MacAskill 2007). Turkey got the targets for the strike from intelligence given to them by the United States (Tyson and Wright 2007). On December 18, Turkish troops entered Iraq to conduct operations against the PKK (Milliyet 2007). In February 2008, with US approval, Turkey conducted an eightday ground offensive into Iraq (Tavernise 2008). These airstrikes and crossborder operations became quite common over the coming months. The American operational assistance to Turkey also helped Ankara by sending a clear signal to the KRG that they needed to adopt more Turkey-friendly positions on outstanding issues such as Kirkuk and their own handling of PKK militants (International Crisis Group 2008:10). In November 2008, the United States and Iraq signed a Status of Forces Agreement that made the Kurdish Regional Government officially responsible for security in northern Iraq, meaning that Turkey would now deal with the Iraqi government and the KRG instead of the United States

\section{Shared Problems-Turkey-Syria and Turkey-Iran}

\section{Turkey-Syria}

Syrian Kurds faced repression beginning in the 1950s (Ziadeh 2009:2). The alAssad regime stripped many Kurds of citizenship which meant they could not receive state benefits, access equal education or medical care, work in the public sector, gain access to many professions, vote, own property, or stay in a hotel (Lowe 2006:3). Given these adversities and the ruthlessness of the regime, Syria's Kurds have traditionally not challenged their central government to the same extent as their counterparts in Iran, Iraq, and Turkey. However, by the early 1980s, the PKK was allowed to operate from Syria. Hafez al-Assad allowed this sanctuary for three reasons. First, it allowed him to check Turkish power; the PKK rebellion tied down Turkish military assets and undermined the Turkish economy. Second, he had no reason to feel threatened by Syria's Kurds given their inability to dent the regime's power. It is worth emphasizing here that Hafez al-Assad was able to use the PKK precisely because they presented no domestic challenge to him but did present such a challenge to Turkey. In other words, differential threat perception helps explain the very origins of Turkish-Syrian enmity in the early 1980s as 
well as the changing dynamics of the Turkish-Syrian relationship discussed here. Finally, it gave him a lever against Turkey in ongoing water disputes surrounding the Euphrates; al-Assad could trade ending his support for the PKK for a more generous Turkish water policy (Hale 2012:124).

In 1998, Turkey gave Syria an ultimatum: expel the PKK and its leader Abdullah Öcalan or risk war (Olson 2001:110-113). Given Turkey's decisive military advantage, Assad expelled Öcalan. Following this, the PKK and Iraqi Kurdish leaders began allowing Kurdish activists over whom they held sway to criticize the al-Assad regime; roughly simultaneously, a KDP-aligned Syrian Kurdish political party (Yatiki) began openly pushing for more autonomy for Syria's Kurdish regions (Gambill 2004). In 2002 and early 2003, they became even bolder and organized two public protests in Damascus (Gambill 2004). Many of these activists believed that Bashar al-Assad would be more tolerant of dissent than his father and wanted to test the new leader (Sinclair and Kajjo 2011). Notwithstanding these events, Bashar al-Assad still had little reason to feel threatened by his country's Kurdish minority. Indeed, the extent to which he did not fear them is evidenced by his removal of much of the security apparatus from the Kurdish regions (Sinclair and Kajjo 2011). In the lead-up to the US invasion of Iraq then, Syria's Kurds might no longer be helping as a foil against Turkey and might be becoming a nuisance, but they were not posing a direct threat to the regime while the historic enmity between Syria and Turkey precluded the Assad regime from cooperating with Ankara over policy toward the Kurds. ${ }^{13}$ When Syrian Prime Minister Mustafa Miru met with Turkey's Deputy Prime Minister Abdullah Gul, though they discussed Iraq generally, the issues of the PKK and of Turkey's troops entering Iraq were not on the agenda (Anatolia Turkish News Agency 2003).

The Syrian regime's threat perception of the Kurds began to change as Iraqi Kurds started making real gains in late 2003. An additional factor was that 710,000 Syrians in the PKK left to create their own organization, the PYD, aimed at fighting for greater autonomy in Syria (Barfi 2013). The PYD's armed wing received training from the PKK in Iraq's Qandil Mountains (International Crisis Group 2013). There was also a concern that given's Iraqi Kurds' assistance to the United States, if the United States attacked Syria, Syria's Kurds might fight alongside the Americans (KurdWatch 2009:15). The Syrian government's perception that Kurdish groups could challenge the Syrian state through either terrorism or calls for greater autonomy was becoming more acute. In response in January 2004, Bashar al-Assad became the first modern Syrian leader to visit Turkey; the Kurdish issue was a central point of his meetings with Turkish President Sezer (Milliyet 2004a).

This change in Syria's threat perception of the Kurds accelerated in spring 2004. The passage of the TAL in Iraq in March 2004 emboldened Syrian Kurds (Lowe 2007:305; Sinclair and Kajjo 2011). For people with few rights, the notion that their brethren next door could have something close to a state of their own was a heady idea. Barzani and Talabani both gave clear signals that they would help Syria's Kurds push for greater internal independence, which further encouraged this idea (Gambill 2004). Meanwhile, the PKK's camps in Iraq had the effect of training and radicalizing Kurdish militants who would then infiltrate into Turkey and Syria (Brandon 2007). Four days after the TAL's passage, in Qamishli, after altercations between Arabs and Kurds at a soccer match, Syrian forces fired into a Kurdish crowd, killing nine; in response, Kurds rioted, razing buildings and

\footnotetext{
${ }^{13}$ While the Syrian government did cooperate to the extent that it expelled Öcalan in 1998, from 1999 until 2003, there was not any real cooperation, and there was simply a lack of open conflict. If it were Turkish coercion that really produced cooperation between the two, we should have seen much more of it during this time period. That we did not suggests that later cooperation was driven more by shared threat perceptions than Turkish coercion.
} 
vehicles (Lowe 2010:168; KurdWatch Report 4 2009). In the following days, similar uprisings erupted in Aleppo, Afrin, and Qamishli again (KurdWatch Report 4 2009; Brandon 2007). In the riots and ensuing crackdown, 40 were killed, 400 injured, and 2000 arrested (Fragiskatos 2007:114). The uprisings were well organized, the selection of which buildings to raze was deeply political, and the assistance of Iraqi Kurdish groups was clear (Gambill 2004). The threat of unrest and calls for greater autonomy for Syria's Kurds was no longer a potential threat; it was a real one.

This uprising, known as the serhildan, was the first time that all of Syria's Kurdish areas revolted simultaneously and was the largest challenge to the regime since the 1982 Hama rebellion (Lowe 2010:175-176). Days later, Kurds pulled down a statue of Hafez al-Assad in a manner reminiscent of the toppling of Saddam's statue in Baghdad less than a year earlier (Lowe 2010:169). Even in more stable times, these acts would not have been tolerated, but given the context in which they occurred and Bashar al-Assad's recent ascension, they were seen as an extraordinary threat to the regime because Syrian officials feared the possibility that Kurdish antigovernment protests could morph into a more general nationwide protest and so Damascus labeled the Kurdish areas a threat to national security (Shifrinson 2006:2; Ziadeh 2009:6). The government's repression measures fell disproportionately on PYD members because the Assad regime perceived them to be the uprising's ringleaders (International Crisis Group 2013:12). Further unrest and repression occurred after Syrian personnel murdered a popular Kurdish religious leader, Sheikh Khaznawi, because he was attempting to politically connect Kurdish groups with the Muslim Brotherhood (Lowe 2007:306; KurdWatch Report 4 2009:17). To undermine this kind of multi-ethnic cooperation, the Assad regime enlisted Arab civilians in their repression of the Kurds (Kurdwatch 2009:18). The Syrian government also ended its unofficial practice of not detaining high-profile political leaders (Sinclair and Kajjo 2011).

With Syria's threat perception of the Kurds now aligned with Turkey's, greater cooperation began. Turkey and Syria began conducting high-level meetings to coordinate policy toward the Kurds and started sharing more intelligence while Syria launched more operations against the PKK (Shifrinson 2006:4). ${ }^{14}$ Turkey and Syria, along with Iran, began collaborating to promote Iraq's territorial integrity, secure borders, stymie the PKK, and push back against the Kurdish desire for a weaker federation (Park 2005:41). The Syrian government was especially keen to detain members of the PYD since this allowed them to undermine the most effective Syrian Kurdish political organization while impressing the Turks, who considered the PYD a branch of the PKK (Sinclair and Kajjo 2011).

Coordinating policy vis-à-vis the Kurds created an opportunity for greater policy coordination in other areas. In 2004, the two states agreed to remove many of the land mines along their border and establish a trade consulate in Gaziantep (Hürriyet 2004). Later that year, Turkey agreed to pump water from the Tigris River to help satiate Syria's water needs (Hale 2007:136). In 2005, Turkey and Syria agreed to establish a free-trade zone and began working toward forming a joint oil exploration venture and a shared electricity grid along their border (Fuller 2008:96). Also in that year, Turkish President Sezer defied the United States by visiting Damascus (Radikal 2005). Between 2005 and 2007, Turkey invested more than $\$ 150$ million in 30 different projects in Syria (Gordon and Tasspinar 2008:58). Syria joined the Iraq Neighbors Initiative created by Turkey (Altunışık and Tür 2006:229). Turkish-Syrian trade grew quickly; from 2002 to 2010 , annual trade between them grew from $\$ 500$ million to $\$ 2.3$ billion (Hale

\footnotetext{
${ }^{14}$ To give just one example of this issue's growing importance and Turkish-Syrian cooperation, on July 13, 2004, when faced with a scheduling conflict, Prime Minister Erdoğan chose to meet with Syrian Prime Minister Naji al-Utri rather than the Israeli Prime Minister (Hale 2007:135).
} 
2012:234). This was especially beneficial for cities along the border such as Hatay, Gaziantep, and Urfa. The two states agreed to upgrade border facilities at Nusaybin, which would allow Turkish-Iraqi trade to be channeled around Iraq's Kurdish Regional Government (Tejel 2009:81). In February 2006, Prime Minister Erdoğan proposed a meeting between Iraq's neighbors to coordinate policy (Hale 2007:177). By the end of 2006, Syria, again along with Iran, was extraditing PKK members to Turkey (Economist 2006). Syria even offered to assist Turkey in carrying out an amnesty offer being negotiated between the Turkish government and the PKK (International Crisis Group 2011:33). When Turkey launched its incursion into northern Iraq Bashar al-Assad immediately supported it (Phillips 2011:36). Turkey and Syria conducted joint military exercises along their shared border (April 2009), opened their border to visa-free travel (October 2009), and Turkish Prime Minister Erdoğan visited Damascus for more high-level talks (December 2009) (Hale 2012:234-235). By 2010, Turkish-Syrian cooperation on the Kurdish issue was all but comprehensive (Hale 2012:147). The main impetus behind this cooperation was the two states' shared threat perception of the Kurds.

\section{Turkey-Iran}

In contrast to Syrian Kurds, Iranian Kurds have repeatedly challenged their government. After the Iranian Revolution, Kurds wanted more autonomy under the new regime (McDowall 2004:261). The new regime feared separatism so it suppressed the Kurds. Less than a month after Khomeini returned from exile, a battle between Khomeini's forces and Kurdish fighters killed 100 (McDowall 2004:261). In repeated rebellions lasting into 1983, more than 10,000 Kurds were killed (McDowall 2004:262). In the early 1990s, Iran assassinated more than 200 Kurds in Iraq and repeatedly used their artillery to shell Kurdish-controlled border areas of Iraq and Iran (Ahmadzadeh 2010:186). Even under reformist leader Mohammad Khatami, continued persecution of the Kurds left 30 dead, hundreds wounded, and 2,000 jailed (McDowall 2004:279). That Iran's Kurds are predominantly Sunni provides an additional excuse for the regime to suppress them (Economist 2000).

Historically, Turkey and Iran have not worked closely together. The Ottoman and Persian Empires were longtime rivals and even in modern times, while the two states have had a peaceful border, their relationship has often been defined by mutual suspicion and competing interests (Guzansky and Lindenstrauss 2011:95). Their relations in the 1990s were frequently tense (Hale 2012:238). These suspicions, along with competing nationalisms and sectarian antipathy, continued to influence Iranian policymakers' opinion of Turkey even after the election of the AKP in Turkey in 2002 (Jenkins 2012:29-30). After the US invasion, most other factors would have pointed toward friction between the two states. They were in competition for leadership in the wider region and for influence in Iraq in particular. Iran's nuclear program naturally concerned Turkey, though not to the same degree as it did the United States and Israel. For most of this period, Turkish-Israeli relations remained on a solid footing, which of course ran in the opposite direction of Iran's policy toward Israel. ${ }^{15}$ Turkey and Iran also had competing interests and opposing policies with regard to the Trans-Caspian Pipeline, Turkey's support for Azerbaijan (which has traditionally had poor relations with Iran), and Iran's alignment with Russia and Armenia (which have traditionally had poor relations with Turkey) (Jenkins 2012:46-47). Thus, this

\footnotetext{
${ }^{15}$ As Jenkins (2012:30) points out, "Jewish organizations in the U.S. lobbied vigorously on the AKP's behalf with the government in Washington, while Turkey continued to award lucrative defense contracts to Israeli companies." Turkish-Israeli relations did not turn sour until Israel's Operation Cast Lead in 2008.
} 
relationship presents a hard case for the power of transnational groups seen as a shared problem to encourage cooperation.

After the US invasion, Tehran and Ankara both perceived the Kurds as a threat. As a shared problem, the Kurdish issue fostered cooperation between them. Changes in the amount of cooperation tracked changes in the alignment of the two states' threat perceptions. Iran shared Turkey's worry that greater autonomy for Iraqi Kurds could ignite calls for greater autonomy in Iraq's neighbors and thus shared Turkey's opposition to an independent Kurdish state in Iraq. Furthermore, the Iranians were eager to check gains made by Iraq's Kurds because those gains might come at the expense of Iraq's Shia. These shared incentives meant that Turkish-Iranian relations improved markedly in 2003, and much as with Syria, the Kurdish challenge was the most important single factor in driving that rapprochement (Park 2005:42).

This improvement accelerated in 2004 and did so for three reasons. First, both states highly disapproved of the TAL. Turkey did so for previously discussed reasons and Iran did so because it believed the TAL did not give enough authority to the central government or enough representation to the Shia. Second, the TAL generated the same kind of unrest and demands for autonomy in Turkey and Iran as they had in Syria. Just after the TAL was passed in March, Iranian Kurds organized a large protest that resulted in 100 arrests (McKiernan 2006:306). Finally, and most importantly, each state's Kurdish terrorism problem worsened. While the PKK was escalating its attacks in Turkey, an offshoot of the PKK, the PJAK, was established and began launching attacks in Iran (Park 2005:44) ${ }^{16}$ The PJAK was much more militant in its tactics than other Iranian Kurdish organizations at the time (Shifrinson 2006). Just as Turkey suspected the United States of helping the PKK, Iran believed the United States was helping the PJAK (Ahmed 2007:284; Ahmadzadeh 2010:180). There was some credibility to this belief. Zinair Mustafa, one of the PJAK's leaders, said that "the Americans just wink at PJAK's operations" (Hastings, Matthews, Kohen, and Hirsh 2006). At the very least, both states could be confident that the United States would not obstruct the PKK or the PJAK. Therefore, Turkey and Iran began conducting joint operations inside northern Iraq (Milliyet 2004; Park 2005:42). They also began sharing intelligence and working more closely on counterterrorism; these discussions facilitated closer cooperation on a host of issues ranging from energy to double taxation (Hürriyet 2004). In July 2004, the Iranian government officially designated the PKK a terrorist organization (Hürriyet 2004). In November, the Turkish and Iranian interior ministers met again to increase security cooperation (Park 2005:40). As Turkish Interior Minister Beşir Atalay put it, "Iran really helped out. They have their own big problem with PJAK; Iran said, 'we can work together'. We got the same from Syria” (International Crisis Group 2011:6).

In the summer of 2005, Iranian security forces killed Kurdish activist Shivane Qadiri, sparking widespread protests and riots in Kurdish areas (Beeman 2007:277; Entessar 2007:272). By the following month, 100,000 Iranian troops had to be stationed in Kurdish areas to quell the riots (Beeman 2007:278). Meanwhile, fighting between the PJAK and Iranian forces intensified (Entessar 2007: 272). In 2005, the PJAK killed 120 Iranian soldiers (Brandon 2006). As fighting worsened, coordination between Iran and Turkey increased. On August 31, Mehemed Rezazade, the governor of Iran's Xoy region, said that Iran and Turkey had held intelligence meetings and decided to conduct further joint military operations against the PKK/PJAK (Mahabad August 31, 2005). The following year, PJAK attacks in Iran increased again along with PKK attacks in Turkey

\footnotetext{
${ }^{16}$ The PKK "selected PJAK's leader (Hajj Ahmad), [and] appointed its 40-person central committee" (Katzman 2010:12). The PKK also allows PJAK to use its hospitals and to remain inside its territory the Qandil Mountains. (Brandon 2006).
} 
(Daloglu 2006). The PJAK had become a serious security problem for Iran. They had killed many members of the Revolutionary Guard, claimed to have thousands of members inside Iran, and had roughly 3,000 troops in northern Iraq (Brandon 2006; Wood 2006).

Starting in 2006, Turkey and Iran again significantly increased their joint military operations against the PKK/PJAK (Fuller 2008:111). Iranian shelling accompanied Turkish air attacks on PKK bases in northern Iraq (International Crisis Group 2010::11). The Turks and Iranians coordinated a buildup of military forces along the Iraqi border in an attempt to intimidate KRG officials into more aggressively suppressing PKK/PJAK activity (Shifrinson 2006:5). This cooperation allowed the Iranians to juxtapose their policy with US policy. Secretary of the Iranian National Security Council Ali Larijani bragged that while the United States was holding secret meetings with the PKK, Iran was happy to help Turkey with its PKK security problem (NTV Television News 2006). In July 2006, Firuz Dowlatabad, the Iranian ambassador to Turkey, announced that Iran "would fully support Turkish military operations inside northern Iraq against the PKK" (Midya 2006). Over the next two months, Turkey and Iran shared more intelligence and coordinated their movement of tanks, artillery, and troops (Howard 2006). The fight between the PKK/PJAK and Turkey-Iran would continue for the next several years. Additionally, Turkey and Iran began using each other's best practices in addressing the Kurdish challenge; for example, Iran started utilizing the Turkish tactic of employing rural Kurds as local militias so that the PJAK was forced to fight other Kurds rather than focus its energies against the regime (Brandon 2006).

While Iran and Turkey were partnering to crush the PKK/PJAK, they changed their approach to the KRG and nonviolent Kurds in northern Iraq almost simultaneously. Though initially skeptical about helping Iraqi Kurds, Turkey and Iran eventually accepted that a federated status for Iraq was unavoidable and that a stable Kurdish region in Iraq was ultimately good (or at least better than a Kurdish region trying to break away) and so became major investors in the KRG (Katzman 2010). In March 2008, President Ahmadinejad became the first Iranian head of state to visit Iraq since before the Iranian Revolution and there concluded major agreements on electricity, customs, transportation, insurance, industry, and education (Ridolfo 2008). In the same month, Prime Minister Erdoğan announced a $\$ 12$ billion investment package for Turkey's southeastern region, which would increase Turkish trade with the KRG (Milliyet 2008). The AKP government believed that improving economic conditions in the Kurdish region of Turkey would reduce support for the PKK. To augment this strategy, Turkey began conducting talks with Nechirvan Barzani, the prime minister of the KRG, to try to get the KRG leadership to help Turkey fight the PKK (Milliyet 2008). While these deals were often negotiated by the Iraqi central government, they disproportionately benefitted Kurdish areas. The KRG-affiliated Kurds in Iraq did not present the kind of terrorism that the PKK/PJAK did, and by 2008, the threat of a fully independent KRG promoting secession in neighboring Turkey and Iran had receded, meaning that they were not a threat to those states' security. Indeed, if the KRG could be supported and coaxed into restraining the PKK/PJAK, then Turkish and Iranian security could be strengthened.

This belief led Iran and Turkey to invest heavily in the KRG. In 2007, Iranian exports to the KRG stood at \$1 billion, about one-third of all Iran-Iraq trade (Kurdistan Board of Investment, Trade and Industry Official Web site). Iran's trade with Iraq stood at 4.5 billion dollars for the first six months of 2011 alone with the KRG receiving 65 percent of that trade (Iraq Insights 2011:1-2). By October 2011, roughly 200 of the 1200 registered companies in Iraqi Kurdistan were Iranian, which constituted a significant increase from 2008 (Iraq Insights 2011:1-2). The improvements in Iran-KRG trade were surpassed only by 
improvements in Turkey-KRG trade. Starting in 2009, significant numbers of business groups backed by the Turkish government began visiting the KRG (AlSharikh 2011:120). Imports from Turkey increased from 18.9 percent of total imports to 29.4 percent from 2008 to 2010 (Iraq Insights 2011:1). By 2011, 80 percent of the food in the KRG was from Turkey, 60 percent of the businesses in the region were Turkish businesses, and the Turkish government was aiming to increase annual trade from $\$ 9$ billion to $\$ 20$ billion within five years (Al-Sharikh 2011:114). Turkey and Iran became the primary sources of foreign direct investment for the KRG (Kurdistan Board of Investment, Trade and Industry Official Web site). This stratagem was not entirely altruistic. By increasing trade with the KRG, Turkey made the KRG dependent on it and so could more easily pressure the KRG into suppressing the PKK (International Crisis Group 2008:13; AlSharikh 2011:121). Iran could make similar demands regarding the PJAK.

\section{Conclusion}

This article engaged in theory-building and case study analysis. Further research can be done by quantitatively testing hypotheses related to transnational groups. Unfortunately, existing data sets such as the Militarized Interstate Dispute data set and the International Crisis Behavior Project data set lack the necessary variables to perform such analysis. Still, any progress that can be made in advancing our understanding of transnational groups' impact illuminates an important aspect of international security relations.

While this article is specifically about the Kurds, it helps explain the international security relationships that arise around other transnational groups as well. If we take a look back at the $2 \times 2$ chart presented earlier, we could easily place other cases within this framework and make fairly accurate predictions about the international security relations that emerge in those cases.

The Catalonians in Spain and France are an example of a transnational group that does not activate the cooperative and conflictual dynamics in security relations because they do not challenge either state's Westphalian sovereignty through terrorism or violent pushes for independence. There have been significant expressions of separatist sentiment such as the Catalan Way, a protest that involved thousands of people linking arms to create a human chain 250 miles long (Minder 2013). Crucially though, these acts are not violent. The Mapuche in Chile and Argentina also fit into this quadrant.

There are a number of examples that fit in the lower left and upper right quadrants. After Hutu militias left Rwanda in 1994, they reorganized in Zaire with the aid of Mobutu Sese Seko's regime (Human Rights Watch 1995). These armed Hutu groups posed no threat to Seko's regime, but they were clearly an extraordinary threat to the Tutsi government in Rwanda, especially after they started conducting raids inside Rwanda (Lorch 1995). Zaire's refusal to assist Rwanda in suppressing them quickly led to conflict between the two states; as two scholars put it "Hutu militias thus played a definitive role in leading the two countries into overt war in 1996 and again in 1998" (DeRouen and Heo 2007:665). The insurgency against the pro-Western government in Ukraine that began in late February 2014 also fits here. Moscow is able to use armed groups of ethnic Russians as a crossborder challenge to the pro-Western government in Kiev precisely because they obviously do not present a threat to Russia but do present a threat to the Ukrainian government. Another example of different threat perceptions creating friction between two states occurred in July 2010 when Colombian President Uribe presented evidence that Venezuela was covertly supporting the FARC, which led to a diplomatic breakdown between them ("Terrorists on Video; Colombia Proves Again That Venezuela is Harboring FARC Insurgents" July $30,2010)$. Venezuela was only able to do this because the FARC rebels present a 
Differential Threat Perceptions

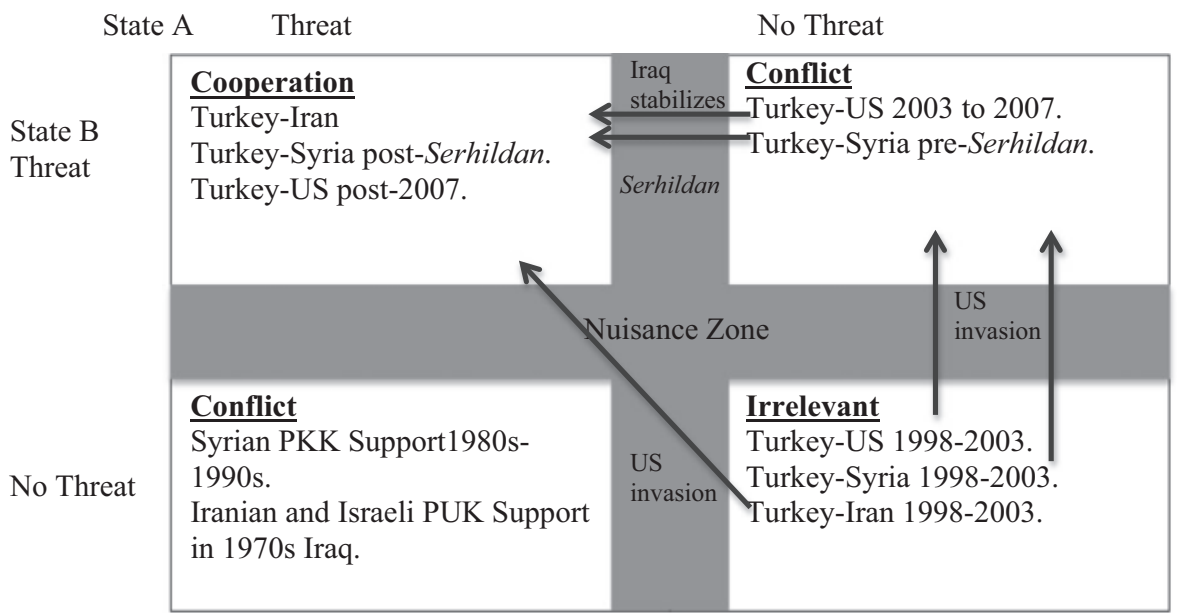

threat to Colombia but not to Venezuela. Similarly, the Pakistani ISI has been able and willing to support Sikh militants because they threatened India, but not Pakistan (Khan 2009).

Conversely, Hizb ut-Tahrir has been perceived as a threat by all of the Central Asian states it resides in. Hizb ut-Tahrir is an extremist group in Central Asia that denies the legitimacy of the existing and advocates for the construction of a new Caliphate (Ayoob 2007:138-142).

Not only do the Central Asian states repress Hizb ut-Tahrir individually but they also work together against this shared nuisance; in August of 2006, Uzbekistan, Kyrgyzstan, Kazakhstan, Tajikistan, and Russia conducted joint operations to combat cross-border movements of transnational terrorists ( $B B C$ Monitoring Central Asia 2006). Similarly, Mali and Niger began to coordinate their security policies along their shared border after the beginning of the Taureg Rebellion (IRIN News Agency 2007).

This article's findings have implications for both transnational groups and states. For transnational groups, it seems clear that whatever long-term goals and ideology may dictate, it is imperative that the group not alienate (and preferably help) the regime in at least one state in which they reside. Had Kurdish groups only threatened Turkey but not Iran and Syria, it is unlikely that Turkey would have gained those states' assistance in repressing Kurdish groups. For states, it seems equally clear that sharing a transnational threat with another state provides a window to improve relations more broadly. Cooperating on security matters related to Kurdish groups facilitated broader cooperation that would have been improbable without that catalyst.

The Kurds are a prominent example of a group that resides on multiple sides of international borders, but they are far from the only such group. It is frequently the case that the boundaries of a state are not coterminous with national boundaries. States that contain a politically salient group that can also be found in another state are, in many regions of the world, the rule rather than the exception. Given this, understanding the political dynamics that emerge from these situations is critical for understanding international relations at a more general level. This article has added to that by analyzing how one transnational group, the Kurds, affected the respective foreign policies and international relationships of 
four states and by suggesting how lessons from studying this set of cases can illuminate international relations more broadly.

\section{References}

Ahmadzadeh, Hashem. (2010) Kurdish Political Mobilization in Iran. In The Kurdish Policy Imperative, edited by Robert Lowe, and Gareth Stansfield. London: Chatham House.

Ahmed, Mohammed. (2007) Laying the Foundation for a Kurdistani State in Iraq: 1991-2006. In The Evolution of Kurdish Nationalism, edited by Mohammed Ahmed, and Michael Gunter. Costa Mesa, CA: Mazda.

Al-Sharikh, Khaled. (2011) Erasing the Frontier: Turkey's Trade and Investment in Iraqi Kurdistan. New Initiative for Middle East Peace Insights 6: 114-132.

Altunişik, Meliha Benli, and Özlem Tür. (2006) From Distant Neighbors to Partners? Changing Syrian-Turkish Relations. Security Dialogue 37: 229-248.

Anatolia Turkish News Agency. (2003) Syrian Premier's Contacts in Turkey Detailed. BBC Summary of World Broadcasts, July 29.

Asik, Melin. (2003) CHP Müsameresi. Milliyet, February 7.

Ayoob, Mohammed. (1992) The Security Predicament of the Third World State: Reflections on State Making in a Comparative Perspective. In The Insecurity Dilemma: National Security of Third World States, edited by Brian Job. Boulder: Lynne Rienner.

Ayooв, Монамmed. (2007) The Many Faces of Political Islam: Religion and Politics in The Muslim World. Ann Arbor: University of Michigan Press.

Barfi, BARAK. (2013) The Fractious Politics of Syria's Kurds. WINEP Policywatch 2184, December 18.

Barkey, Henri. (2005) Turkey and Iraq: The Perils (and Prospects) of Proximity. Special Report 141. Washington, DC: United States Institutes of Peace.

BBC Monitoring Central Asia. (2006) Central Asian States, Russia Launch Joint Antiterror Operation. Text of report by Kyrgyz news agency 24.kg, August 8.

BBC Monitoring Europe. (2006) Roundup of Turkish Press Comment on USA's Rice Visit, April 26.

Beeman, William. (2007) Iran and Kurdistan: A Studied Ambiguity. In The Evolution of Kurdish Nationalism, edited by Mohammed Ahmed and Michael Gunter. Costa Mesa, CA: Mazda.

Brandon, James. (2006) Iran's Kurdish Threat: PJAK. Terrorism Monitor 4: 12.

Brandon, James. (2007) The PKK and Syria's Kurds. Terrorism Monitor 5: 3.

ÇEVIKCAn, SerPIL. (2002) Türkiye'ye tehdit Kuzey Irak'tan. Milliyet, December 29.

Daloglu, Tulin. (2006) The PKK Threat to Turkey; US Policy Sidesteps Real Issue, Washington Times, April 26.

Davis, David, And Will Moore. (1997) Ethnicity Matters: Transnational Ethnic Alliances and Foreign Policy Behavior. International Studies Quarterly 41: 171-184.

DeRouen, Karl, and Uk Heo, Eds. (2007) Civil Wars of the World: Major Conflicts Since World War II. Santa Barbara, CA: ABC-CIIO.

DeYoung, Karen. (2007) Balkanized Homecoming. Washington Post, December 16.

Dilanian, Ken. (2004) Turkey Eases Repression of Its Kurds. Philadelphia Inquirer, October 4.

Dismorr, Ann. (2008) Turkey Decoded. London: Saqi.

Dodge, Toby. (2005) Iraq's Future: The Aftermath of Regime Change. International Institute of Strategic Studies. New York: Routledge.

Dogan, Yalçın. (2003) ABD-Kürt pazarligi devlet üzerine. Hürriyet, February 28.

Dombey, Daniel. (2007) Bush to Step Up Military Cooperation with Turkey. Financial Times, November 6.

ECONOMIST. (2000) Iran's Kurds: The Lucky Ones? December 21.

ECONOMIst. (2006) Lonesome Rebels: Turkish Kurds in Iraq, December 16.

ECONOMIST. (2009) Iraq and Its Kurds: Not so Happy, February 19.

Entessar, Nader. (2007) The Kurdish National Movement in Iran Since the Islamic Revolution of 1979. In The Evolution of Kurdish Nationalism, edited by Mohammed Ahmed, and Michael Gunter. Costa Mesa, CA: Mazda.

Filkins, Dexter. (2003) Threats and Responses: Turkey Assess Question of Kurds. New York Times, February 21.

Fox News. (2003) Wolfowitz: Turkey Made 'Big Mistake' in Denying Land, March 28.

Fragiskatos, Peter. (2007) The Stateless Kurds in Syria: Problems and Prospects for the Ajanib and Maktumin Kurds. The International Journal of Kurdish Studies 21: 109-122. 
Fuller, Graham. (2008) The New Turkish Republic: Turkey As A Pivotal State in The Muslim World. Washington, DC: United States Institute of Peace Press.

Gambill, Gary. (2004) The Kurdish Reawakening in Syria. Middle East Intelligence Bulletin 6: 4.

Gause, Gregory. (2009) International Relations of the Persian Gulf. New York: Cambridge University Press.

Gordon, Phillip H., and Omer Taşpinar. (2008) Winning Turkey: How America, Europe, and Turkey Can Revive A Fading Partnership. Washington, DC: Brookings Institution Press.

Gunter, Michael. (1998) Turkey and Iran Face Off in Kurdistan. Middle East Quarterly 5: 33-40.

Guzansky, Yoel, and Gallia Lindenstrauss. (2011) Turkey and Iran: The Politics of Strange Bedfellows. Strategic Assessment 14: 95-108.

Hale, William. (2007) Turkey, the US, and Iraq. London: Saqi.

Hale, William. (2012) Turkish Foreign Policy since 1774, 3rd edition. New York: Routledge.

Hastings, Michael, Owen Matthews, Sami Kohen, and Michael Hirsh. (2006) Blacksnake’s Lair, Newsweek, October 9.

Hawlati Kurdish newspaper. (2007) Turkish Officers Killed during Fighting with Kurdish Rebels in Iran. BBC Monitoring Middle East, August 19.

Howard, Michael. (2006) Kurds Flee Homes as Iran Shells Iraq's Northern Frontier. The Guardian, August 17.

Human Rights Watch. (1995) Rearming with Impunity: International Support for the Perpetators of the Rwandan Genocide. 7(May) :4.

HürRIYET. (2004a) Kapımızı açtık, bekliyomuz, January 9.

HÜRRIYET. (2004b) Erdogan: Iran PKK için gerekeni yapacak, July 28.

HÜRRIYET. (2004c) Iran: PKK terörist, July 29.

HÜRRIYET. (2004d) Amaç Telaferi Kürtlere vermek, September 12.

HÜRRIYET. (2004e) Gül: ABD’nin yanlisini yetkililere söylüyoruz, November 26.

HÜRRIYET. (2006a) Sirnak'ta 5 asker, Bingöl'de 1 polis sehit, April 5.

HÜ RRIYET. (2006b) 3 günde 15 şehit anlay?s? m?z? aşt?, July 21.

International Crisis Group. (2008) Turkey and Iraqi Kurds: Conflict or Cooperation? Middle East Report 81, November 13.

International Crisis Group. (2010) Turkey?s Crises Over Israel and Iran. Europe Report 208 (September 8).

International Crisis Group. (2011) Turkey: Ending the PKK Insurgency. Europe Report 213, September 20.

International Crisis Group. (2013) Syria’s Kurds: A Struggle Within a Struggle. Middle East Report 136, January.

IRAQ Body Count. Available at https://www.iraqbodycount.org. (Accessed June 8, 2012.)

IRAQ INSIGHTS. (2011) Iraq's Trading Partners: Changing Allegiances. Vol. 5, October.

IRIN News AgENCY. (2007) Mali-Niger: Border Security Cooperation Reinforced, August 24.

Jenkins, Gareth. (2012) Occasional Allies, Enduring Rivals: Turkey's Relations with Iran. Silk Road Paper. Washington, DC: Johns Hopkins Press.

Katzman, Kenneth. (2010) The Kurds in Post-Saddam Iraq. Congressional Research Service Report 75700, October 1. Washington, DC: Congressional Research Service.

Kaya, Karen. (2012) A Different War on Terrorism: The US, Turkey, and the PKK. Small Wars Journal, May.

Khan, Mukhtar. (2009) India's Sikh Militants Forming Ties with Lashkar-e-Taiba and Pakistani Intelligence. Terrorism Monitor 7: 1.

Krasner, Stephen. (1999) Sovereignty: Organized Hypocrisy. Princeton: Princeton University Press.

Kurdistan Board of Investment, Trade and Industry. Official Website Available at http://www.kurdistaninvestment.org/trade_industry.html. (Accessed July 2, 2012.)

KundWatch Report 4. (2009) The Al-Qamishli Uprising: The Beginning of a New Era for Syrian Kurds? Berlin: European Center for Kurdish Studies, December.

Lorch, Donatella. (1995) Fearing Attack by Hutu Exiles in Zaire, Rwanda Bolsters Its Defenses. New York Times, August 9.

Lowe, Robert. (2006) The Syrian Kurds: A People Discovered. London: Chatham House Middle East Programme Briefing Paper, January.

Lowe, Robert. (2007) Kurdish Nationalism in Syria. In The Evolution of Kurdish Nationalism, edited by Mohammed Ahmed and Michael Gunter. Costa Mesa, CA: Mazda.

Lowe, Robert. (2010) The Serhildan and the Kurdish National Story in Syria. In The Kurdish Policy Imperative, edited by Robert Lowe, and Gareth Stansfield. London: Chatham House. 
MacAskill, Ewen. (2007) Turkey Launches Biggest Bombing Raid on Kurdish Rebels in Iraq. The Guardian, December 17.

Mahabad Mesopotamian News Agency. (2005) Kurdish Paper Reports Turkish-Iranian Intelligence Talks Held. BBC Monitoring Middle East, September 1.

Mango, Andrew. (2004) The Turks Today. New York: Overlook Press.

Marcus, AlizA. (2007) Blood and Belief: The PKK and the Kurdish Fight for Independence. New York: New York University Press.

Matthews, Owen, Seth Colter Walls, Sami Kohen, Kevin Peraino, and Michael Hastings. (2007) It's Not About The West. Newsweek International Edition, November 5.

McDowall, David. (2004) A Modern History of the Kurds, 3rd edition. New York: I.B. Tauris.

McKiernan, Kevin. (2006) The Kurds: A People in Search of Their Homeland. New York: St. Martin's Press.

Midya IraQi Kurdistan Newspaper. (2006) Iran Supports Turkey's Plan to Attack PKK in North Iraq. BBC Monitoring Middle East, July 25.

MILLIYET. (2003a) Kürtler petrol üretimine basladi, April 17.

MILLIYET. (2003b) Bu nasıl müttefik, July 6.

Milliyet. (2003C) PKK'dan ateskes bitti tehdidi, September 3.

Milliyet. (2004a) Esaddan ailece beyaz sayfa, January 7.

MILLIYET. (2004b) Iran, PKK'ya roket yagdirdi, October 2.

Milliyet. (2005A) Rice: Turkiye ÖZzel Örnek, February 7.

Milliyet. (2005b) ABD ile yeni dönem, June 9.

Milliyet. (2005c) Tek Devlet Tek Millet Tek Bayrak, August 13.

Milliyet. (2006A) Canli bomba Dehseti, March 10.

Milliyet. (2006B) Gabar'da ÇATisma: 1 SEhit, March 13.

Milliyet. (2007A) Tekere Tamam, October 18.

Milliyet. (2007в) PKK'ya balistik füZe süprizi, December 3.

Milliyet. (2007C) SON Yillarin en büyüK SAldirisi, December 18.

Milliyet. (2008A) ERdogan'in Yok dedigi gÜNEYdogu paketi 12 Milyar, March 12.

Milliyet. (2008в) ERbil, Gül'ü BekliYor, October 13.

Minder, Raphael. (2013) Hand in Hand, Catalonians Press Their Case. International Herald Tribune, September 12.

Myers, Steven Lee. (2007) Bush Pledges to Help Turkey on Intelligence. New York Times, November 6.

NTV Turkish Television. (2003a) USA Should Take Concrete Step against Kurdish Militants Turkish Minister. Report by Turkish NTV television. BBC Summary of World Broadcasts, September 26.

NTV Turkish Television. (2003b) Deputy Premier: Turkey Banned Entering Iraq Unilaterally by US Loan. BBC Summary of World Broadcasts, September 30.

NTV Turkish Television. (2006) Iran's Larijani Lauds Ties with Turkey, Criticizes US Policies. BBC Monitoring Europe, May 8.

Olson, Robert. (2001) Turkey's Relations with Iran, Syria, Israel, and Russia, 1991-2000. Costa Mesa, CA: Mazda.

PARK, Bill. (2005) Turkey's Policy Towards Northern Iraq: Problems and Perspectives. International Institute of Strategic Studies. New York: Routledge.

Phillips, Christopher. (2011) Turkey's Global Strategy: Turkey and Syria. IDEAS Reports - Special Reports, edited by Nicholas Kitchen. SR007. London: LSE IDEAS, London School of Economics and Political Science.

RADIKAL. (2003) Meclis savas'i reddeti, March 1.

RADIKAL. (2005) Sezer: Suriye büyük, April 15.

Ridolfo, Kathleen. (2008) Iraq; Sunnis Say Iran Working to Solidify Economic Control. Radio Free Europe Radio Liberty, March 5.

Saideman, Stephen. (2001) The Ties That Divide: Ethnic Politics, Foreign Policy, and International Policy. New York: Columbia University Press.

Salehyan, Idean. (2010) Transnational Insurgencies and the Escalation of Regional Conflict: Lessons for Iraq and Afghanistan. New York: Strategic Studies Institute.

Shaikh, Thair. (2007) Kurds Implicated in Ankara Bomb Attack. The Independent (London), May 23.

Shemesh, Moshe. (2002) The IDF Raid on Samu': The Turning-Point in Jordan's Relations with Israel and the West Bank Palestinians. Israel Studies, 7: 139-167.

Shifrinson, Joshua. (2006) The Kurds and Regional Security: An Evaluation for Developments since the Iraq War. Crown Center for Middle East Studies. Middle East Brief 14: 1-10.

Sinclair, Christian, and Sirwan KajJo. (2011) The Evolution of Kurdish Politics in Syria. Middle East Report, August 31. 
Tahiri, Hussein. (2007) The Structure of Kurdish Society and The Struggle for The Kurdish State. Costa Mesa, CA: Mazda.

TAvernise, Sabrina. (2008) Turkey Planning to Invest Billions to Improve Lives of Kurdish Minority. International Herald Tribune, March 13.

Tejel, Jordi. (2009) Syria's Kurds: History, Politics, and Society. New York: Routledge.

Terrorists on Video; Colombia Proves Again That Venezuela is Harboring FARC Insurgents. (2010) Washington Post, July 30.

Thomas, Landon. (2003) U.S. Disfavor Drains Turkish Economy. New York Times, March 25.

Turkish Fury at IraQ 'ARrests'. (2003) BBC News, July 5.

Tyson, Ann, And Robin Wright. (2007) US Helps Turkey Hit Rebel Kurds in Iraq. Washington Post, December 18.

Unal, Mustafa. (2012) Counterterrorism in Turkey: Policy Choices and Policy Effects toward the Kurdistan Workers' Party (PKK). New York: Routledge.

Weiner, Mrron. (1971) The Macedonian Syndrome: A Historical Model of International Relations and Political Development. World Politics 23: 665-683.

Weisman, Stephen. (2003) Threats and Responses: Powell Says U.S. Can Wage War on Iraq without Turks. New York Times, March 15.

Wood, Graeme. (2006) Iran Bombs Iraq: Meet the Kurdish Guerillas Who Want to Topple the Tehran Regime. Slate, June 12.

Ziadeh, Radwan. (2009) The Kurds in Syria: Fueling Separatist Movements in the Region? Special Report 220. Washington, DC: United States Institute of Peace Press. 